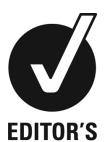

\title{
Circle of Willis: as seen during endoscopic fenestration of a suprasellar arachnoid cyst
}

\author{
Ayoub Dakson, P Daniel McNeely
}

Division of Neurosurgery, Dalhousie University, Halifax Canada

\section{Correspondence to} Dr Patrice Daniel McNeely, dmcneely@dal.ca

Accepted 1 May 2015
CrossMark

\section{To cite: Dakson $A$} McNeely PD. BMJ Case Rep Published online: [please include Day Month Year] doi:10.1136/bcr-2015209424

\section{DESCRIPTION}

A 4-month-old boy presented with progressive macrocephaly and was found to have hydrocephalus (figure 1). A definite lesion was not seen at this time, and he was treated with a ventriculo-

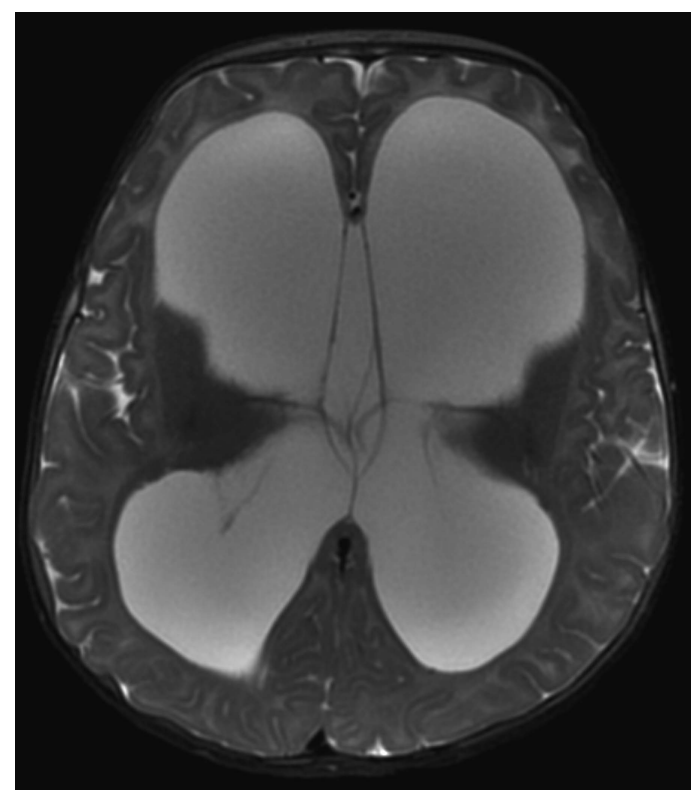

Figure 1 Axial T2 weighted MRI confirming hydrocephalus with severe dilatation of the ventricles.

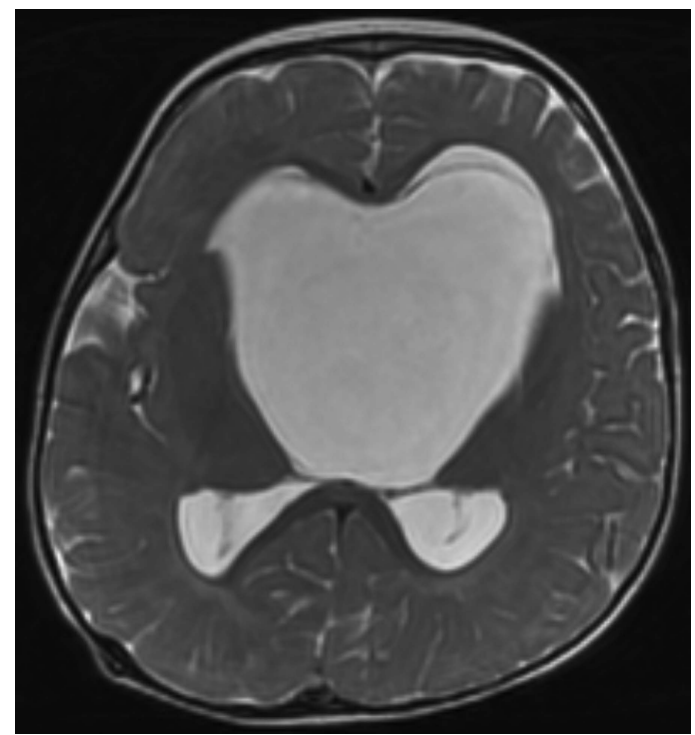

Figure 2 Intraventricular arachnoid cyst causing obstructive hydrocephalus.

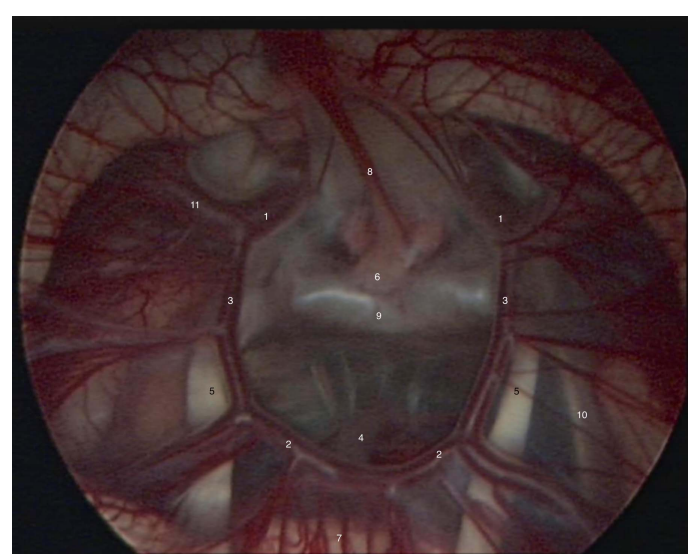

Figure 3 Endoscopic view of the Circle of Willis, showing the internal carotid arteries (1), posterior cerebral arteries (2), posterior communicating arteries (3), basilar artery (4), cranial nerve III (5), pituitary gland (6), midbrain (7), pituitary stalk (8), dorsum sellae (9), right cranial nerve VI (10) and left middle cerebral artery (11).

peritoneal shunt. Upon routine follow-up, he continued to have a head circumference that remained greater than normal percentiles. Repeat imaging at 13 months of age revealed a large suprasellar arachnoid cyst (figure 2). His neurological examination was normal. An endoscopic procedure was performed in order to fenestrate the cyst and treat the persisting hydrocephalus. ${ }^{1}$ During the procedure, the Circle of Willis, pituitary gland and stalk, oculomotor nerves, and midbrain among other fundamental anatomical structures could be clearly visualised (figure 3). The child recovered very well postoperatively and was discharged home 2 days later. He required a repeat endoscopic fenestration procedure 3 years later, but has remained well otherwise.

\section{Learning points}

- The Circle of Willis is a network of anastomotic arteries that joins the internal carotid arteries with each other and with the vertebrobasilar system.

- A complete Circle of Willis is present in most cases, but anatomical variations are common.

- In approximately $60 \%$ of anatomical specimens, one or more vessels are sufficiently narrowed to reduce its role as a potential collateral route. ${ }^{1}$ 
Competing interests None declared.

Patient consent Obtained.

Provenance and peer review Not commissioned; externally peer reviewed.

\section{REFERENCE}

1 Osborn AG. Diagnostic cerebral angiography. 2nd edn. Philadelphia: Lippincott Williams \& Wilkins, 1999:480.

Copyright 2015 BMJ Publishing Group. All rights reserved. For permission to reuse any of this content visit http://group.bmj.com/group/rights-licensing/permissions.

BMJ Case Report Fellows may re-use this article for personal use and teaching without any further permission.

Become a Fellow of BMJ Case Reports today and you can:

- Submit as many cases as you like

- Enjoy fast sympathetic peer review and rapid publication of accepted articles

- Access all the published articles

- Re-use any of the published material for personal use and teaching without further permission

For information on Institutional Fellowships contact consortiasales@bmjgroup.com

Visit casereports.bmj.com for more articles like this and to become a Fellow 